DOI https://doi.org/10.30525/978-9934-26-113-8-20

\title{
AIR ABRASIVE METHOD OF PREPARATION OF HARD TISSUES OF TEETH IN THE TREATMENT OF CARIES
}

\author{
Vakhovskyi V. V. \\ Assistant at the Therapeutic Dentistry Department \\ National Pirogov Memorial Medical University \\ Filimonov V. Yu. \\ Department of Surgery with the Course of Dentistry, \\ Faculty of Postgraduate Education \\ National Pirogov Memorial Medical University
}

Filimonova S. $\mathbf{O}$.

Department of Therapeutic Dentistry

National Pirogov Memorial Medical University

\author{
Androshchuk O. V. \\ PhD, Associate Professor, \\ Department of Pathological Physiology \\ National Pirogov Memorial Medical University \\ Shypytsyna O. V. \\ PhD, Assistant professor, \\ Department of Human Anatomy \\ National Pirogov Memorial Medical University \\ Vinnytsya, Ukraine
}

The prevalence of caries in the world is still very high. Surgical treatment is used most often. The essence of the method is to remove the affected tissues and replace the defect with filling material. The stage of preparation is the most labor-intensive for the doctor and requires considerable effort, experience and modern equipment and tools. [1] Depending on the depth, location of the cavity, age of the patient, the state of oral hygiene and group affiliation of the teeth may be different features of the preparation. To date, there are a number of methods of preparation of hard tissues of the teeth. But the most popular are still rotating tools and the use of turbine and a variety of micromotor tips. However, the preparation of enamel and dentin using boron has a number of disadvantages: vibration, unpleasant sound, overheating of the hard tissues of 74 
the tooth, soreness. Therefore, one of the current problems of modern dentistry is the search for and study of alternative methods of preparation. [2]

The main approaches to preparation today are microinvasiveness and filling only in the presence of a cavity. Initial carious lesions are treated only conservatively, as tooth tissue is capable of remineralization. The main approach in modern preparation technique is to preserve as many viable tissues as possible. [3,5]

The next task of quality preparation is to eliminate factors that can provoke local and general complications. It should be noted that the common factors include psycho-emotional stress, dysfunction of the cardiovascular system, aerosol cloud. [4] Local complications are injuries, microbial invasion.

The main trends in the improvement of preparation methods are the use of modern burs and the latest tips for traditional preparation. At the same time, there is a search for new alternative methods of treatment of hard tissues of teeth: ultrasound, water-abrasive systems, air-abrasive systems, laser and chemomechanical preparation.

Kinetic preparation was first proposed in 1945 by physician Robert Black. The essence of the preparation is the use of point-focused flow of fine particles of

aluminum oxide ( 27 and $50 \mu \mathrm{m}$ ), which is accelerated to $600 \mathrm{~m} / \mathrm{s}$ by airabrasive devices (eg Sandman Futura) and ultrafinely destroys tissues. [6, 7] This is painless non-contact preparation that allows you to remove only the affected tissues, thereby eliminating the shortcomings inherent in the traditional method of preparation, minimizes the risk of complicationsIt should be noted that the use of this technique facilitates the preparation of small cavities. Additional cooling systems are not required, as there is no heating. Microtraumas, chips and cracks of enamel and dentin are practically nonexistent. The surface after treatment remains dry, rough and the efficiency of adhesive systems improves. Particular attention should be paid to the influence of preparation on the future adhesion of the restoration material. According to some authors, the adhesion to enamel is not less than when using traditional preparation, and the adhesion to dentin is better. $[8,9]$. There are a number of disadvantages of kinetic preparation. First of all, it is mechanical contamination and bacterial contamination of the working field. Dental tubules are clogged with fine particles [10].

It is possible to use these devices for other purposes: cleaning fissures, preparation of ceramics before silanization, removal of composites, aggressive removal of stains and plaque, removal of cements, removal of ceramic restorations, preparation for braces, fluorosis treatment, endodontic access through ceramics [11]. 
Therefore, the use of the kinetic method of preparation must be justified. The doctor should be guided by the clinical situation, evaluate the indications for the use of this method and the impact on the hard tissues of the tooth. The issue of improving air-abrasive systems is still open, as shortcomings exist and need to be addressed.

\section{References:}

1. Schnlein T.M. The era of high special development in dentistry. J. Hist.Dent. 2002. Vol. 3. № 50. P. 131-137.

2. Кунин В.А., Шумилович Б.Р. Сравнительная характеристика изменений микроструктуры эмали и дентина под влиянием различных видов одонтопрепарирования.Системный анализ и управление в биомедицинских системах. 2008. Т. 7. № 3. С. 766-771.

3. Николаев А.И., Цепов Л.М. Практическая терапевтическая стоматология: учеб. пособие. 7-е изд. М.: МЕДпресс-информ. 2007. 928 с.

4. Шарова Т.Н., Сунцов В.Г., Бойко В.В. и др. Изучение психоэмоционального и соматического состояния пациентов на стоматологическом приеме. Институт стоматологии. 2008. № 1 (38). С. 96-98.

5. Маунт Гр. Дж. Минимальная интервенция в стоматологии. Новое в стоматологии. 2005. № 2. С. 92-94.

6. Максимовская, Л. Н.; Ситдикова, И. В. Оценка эффективности воздушно-абразивного метода препарирования путем определения прочности соединения композитной реставрации с твердыми тканями зуба после его применения. Стоматология славянских государств. 2018. C. $186-187$.

7. Makedonova J. A., Porowski S. V., Firsova I. V., Fedotov Y. M. Laser Doppler flowmetry in diseases of the oral mucosa. Volgograd scientific medical journal. 2016. No. 1. S. 51.

8. Fedotova M. Yu., Yu. a. Makedonova, Porowski S. V., Firsova I. V. Modern aspects of treatment of erosive lichen planus of the mucous membrane of the oral cavity. Modern problems of science and education. 2016. No. 2. P. 108.

9. Барер Г.М., Овчинникова И.А., Завьялова В.А. Препарирование кариозных полостей с помощью аппарата Air Flow prep K 1. Клиническая стоматология. 2001. № 3. С. 66-68.

10. Firsova I. V., Fedotov, Yu. M., Mikhalchenko V. F., Medvedev A. E. the Effectiveness of treatment postcombination pain with the use of leech therapy and laser therapy. Scientific review. Medical science. 2016. No. 3. P. 139-141.

11. Ламбрехт П. «Sandman Futura» - новая система воздушной препаровки зуба Институт стоматологии. 2007. № 2. С. 107. 